African Catholic 



\title{
African Catholic DECOLONIZATION AND THE TRANSFORMATION OF THE CHURCH
}

\section{Elizabeth A. Foster}

\author{
III \\ III \\ Harvard University Press
}

Cambridge, Massachusetts London, England 
Copyright (C) 2019 by the President and Fellows of Harvard College All rights reserved

Printed in the United States of America

First printing

Cover photo: Monsignor Raymond-Marie Tchidimbo and President Sékou Touré following Tchidimbo's consecration as archbishop of Conakry, May 31, 1962. Courtesy of ACSSp.

Cover design by Jill Breitbarth

$$
\begin{gathered}
9780674239449 \text { (EPUB) } \\
9780674239456 \text { (MOBI) } \\
9780674239432 \text { (PDF) }
\end{gathered}
$$

THE LIBRARY OF CONGRESS HAS CATALOGED THE PRINTED EDITION AS FOLLOWS:

Names: Foster, Elizabeth Ann, 1976- author.

Title: African Catholic : decolonization and the transformation of the Church / Elizabeth A. Foster.

Description: Cambridge, Massachusetts : Harvard University Press, 2019. |

Includes bibliographical references.

Identifiers: LCCN 2018028302 | ISBN: 9780674987661 (alk. paper)

Subjects: LCSH: Catholic Church-Africa-History. | Catholic Church-History-1965- | Decolonization-Africa, French-speaking-

History. | Decolonization-Africa, Sub-Saharan-History. | Christianity and culture-Africa, French-speaking-History. |Christianity and culture-Africa, Sub-Saharan-History.

Classification: LCC BX1675 .F67 2018 | DDC 282 / .670917541-dc23

LC record available at https://lccn.loc.gov/2018028302 
For Sophie and Emily 
